\title{
Training for Applied Port Logistics Management Talents Based on Concept of CDIO Education
}

\author{
Xidong Zhai \\ Tianjin University of Technology and Education, Tianjin, China
}

\begin{abstract}
Aiming at ensuring training quality of applied port logistics management talents, through analyzing the talents training concept of CDIO, combining with characteristics of modern port logistics development, and on the basis of discussing structure of abilities and training goal for the applied port logistics management talents, curriculum system and practical teaching system for port management talents training are constructed, corresponding teaching means and evaluation methods are put forward, and then discussion of strengthening construction of teachers and teaching material construction are carried out.
\end{abstract}

KEYWORD: CDIO; Applicative; Port Logistics; Talents Training

\section{INTRODUCTION}

With increasing development of economic globalization, the port logistics develops rapidly, which makes demands for port logistics management talents further increased, while the development of training for port logistics management talents is in a relatively short time, the talents training system and training mode are yet to be improved, which severely limited the training quality enhancement for port logistics management talents in our country. The port logistic is one kind of the logistics service, if the service can be considered as one kind of special product, there should be process of conceiving, designing, implementing and operating also existed in the service of port logistic, which made possible for CDIO education concept can be applied in the process of port logistics management talents training, the successful experiences from abroad and domestic during the process of talents training, which has important significance for training the applied port logistics management talents.

\section{APPLIED PORT LOGISTICS MANAGEMENT TALENTS}

\subsection{Connotation analysis of the applied port logistics management talents type area}

The multi-function and integration characteristics of port logistics make modern port demand higher level of logistics talents, not only requires rich basic theory of logistics management, and requires more strong port management practice ability, ability for lifelong learning, and team working skills. Therefore, the connotation of the applied port logistics management talents can be definite as follows: practical talents who can meet the requirements of modern port logistics development, with solid port logistics needed knowledge and theory, skillfully hold skills related to port logistics manufacturing and management practice, what whom learnt logistics related knowledge and theory can be applied into manufacturing and management practice of port logistics, and can make further application of innovation, and with good teamwork sprit ability, learning skills and good comprehensive quality that career development required.

\subsection{Structure of abilities analysis of the applied port logistics management talents}

According to teaching program of CDIO, the structure of abilities of the applied port logistics management talents can be summarized as two abilities and one quality, that is key ability, professional ability and comprehensive quality. The key ability includes: the abilities of listening, speaking, reading and writing, interpersonal skills, team communication ability and exchanging idea skills, self-learning and innovation abilities, the ability of information processing and issues addressing; the professional ability mainly refers to the related theory and practical application skills that needed for involving port logistics management, and the ability to carry out conceiving, designing, 
implementing, and operating system under the circumstance of port logistics management application; comprehensive quality that is means good quality such as self-confident, outgoing, selfperfection and toughness that port logistics management talents need to match and the correct world outlook, views on life and values.

\subsection{Goal locating of the applied port logistics management talents training based on CDIO concept}

According to the structural feature of abilities of the applied port logistics management talents and demand characteristics of modern port logistics to logistics management talents, the goal of training for the applied port logistics management talents should be analyzed from three dimensions, as follows:

Dimension of knowledge: It can meet the actual demand for port logistics management and producing, with solid logistics management related theory and knowledge, and can practically applied knowledge and theory related to port logistics what he learnt in port manufacturing and management.

Dimension of ability: Who has strong knowledge and technology application ability, skillfully hold practical ability of port logistics management and producing, and innovation of management skills and application methods can be carried out under the current circumstances.

Dimension of quality: With good professional qualities such as have courage for commitment, optimistic and actively.

\section{CONSTRUCTION OF TRAINING CURRICULUM SYSTEM}

It is required that disciplinary courses in the curriculum program structure for CDIO can support each other, it is allowed that personal skills, interpersonal ability and building capacity of products, process and system can be blended organically in the curriculum program. As such, combines with goal of training for the applied port logistics management talents; curriculum system structure for talents training can be constructed correspondingly, which includes four parts: basic course, introduction, and core course for port logistics management, professional course for port logistics management; and practical course for summarize, and these four kinds of course supports each other, blended organically, and makes knowledge learning, ability training and quality forming were applied throughout the curriculum, and four parts of the curriculum also corresponding to three abilities forming period that is basic ability, core ability and comprehensive ability, as shown in figure 1 .

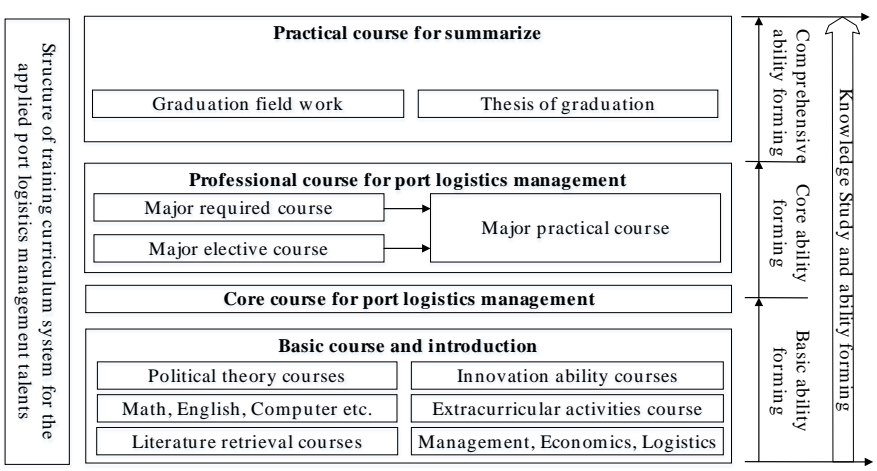

Figure 1.Structure chart of training curriculum system for the applied port logistics management talents

\subsection{Basic course and introduction}

The basic course and introduction is mainly to train the basic ability for students, through some simple curriculum projects, with forms of team works, to guide students hold basic thinking and methods for analyzing and solving problems of administration, to train students' ability of team working and communicating. The basic course emphasizing on training of students' key ability and professional quality, while introduction will help students have common knowledge of logistics and port logistics, so as to arouse students' interest in learning of port logistics.

\subsection{Core course for port logistics management}

On the basis of training students' key ability the core course for port logistics management starts to bring in training of professional ability, to help students hold common abilities and methods that port logistics management activities required, the core course for port logistics management which plays a transiting role in talents training curriculum system, is an important part in the whole curriculum system.

\subsection{Professional course for port logistics management}

The professional course for port logistics management is the important part of talents training system, which includes three parts that are major required course, major elective course and major practical course. Among them, major required course includes two parts that are professional course for logistics management and port logistics, the major elective course during design has showing modeling characteristics, the elective course can be divided into three modules, that are management module, business agency module and port enterprises management module, the students can choose it at will for learning in accordance with their interests and specialty; the students for learning professional practical course are required to carry out practical training on the basis of theory learning, 
focuses on training the skills for conceiving, designing, implementing and operating in port logistics management.

\subsection{Practical course for summarize}

The practical course for summarize after students finished basic and professional knowledge learning, to summarize the knowledge and ability that students learnt, the course of this part mainly includes two parts that are graduation field work and thesis of graduation, which focused on training of students' comprehensive ability, is an embodiment of advanced ability training.

\section{PRACTICAL TEACHING SYSTEM}

The modern port logistics with characteristics of very strong practice, which makes corresponding talents training should match with good practical ability training system. Meanwhile, in the concept of CDIO talents training, which mainly through practical teaching to do design to realize the implement of links, the students mainly through learning process of the link to obtain corresponding application ability and experience. As such, to further detailed requirements of designing-achieving experience for port logistics management, which can be divided into primary skills and experience, middle skills and experience and advanced skills and experience, and then to design corresponding practical teaching system, as shown in figure 2 .

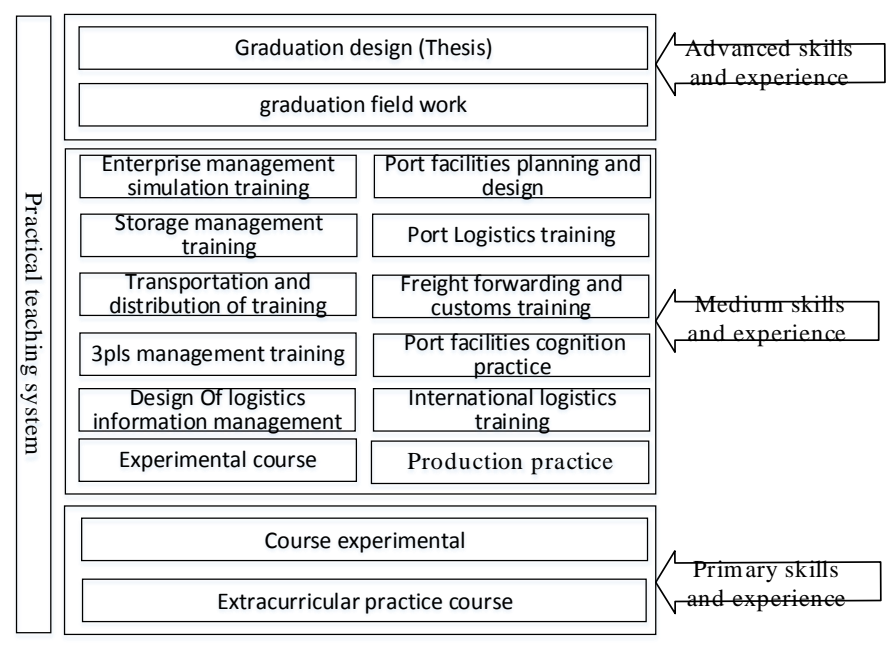

Figure 2.Practical teaching system construction chart for the applied port logistics management talents training

Primary skills and experience focused on training of students' basic ability, to arouse students' learning interests on related knowledge and theory of logistics management, and the corresponding mainly includes extracurricular activities and curriculum experiment. Through forms of designing course survey and interview to get designing-implementing projects, to initially train students' ability of team working and communication.

Primary skills and experience focused on training of students' basic ability, to arouse students' learning interests on related knowledge and theory of logistics management, and the corresponding mainly includes extracurricular activities and curriculum experiment. Through forms of designing course survey and interview to get designing-implementing projects, to initially train students' ability of team working and communication.

The medium skills and experience is mainly on the basis of learning of core course and professional course, to carry out corresponding learning of practical course such as practical training and course designing. The practical course is mainly to stand out ability of actual operation, to further get familiar with and apply knowledge and theory what was learnt; it is required to design specific port logistics management activities for course design-to finish training of links, through forms of simulation and situation simulation to carry out design-to finish learning of links. In addition, the links of production practice also provide an effective way for students to further understanding and applying learnt knowledge and theory.

The advanced skills and experience is mainly for students who comprehensively practical applying learnt knowledge and ability, is one kind of advanced and more complicated design-process of experience got. The advanced skills and experience is mainly acquired by graduation field work and thesis of graduation, during the teaching link of graduation field work, the students were asked to involve into the enterprise, to carry out analysis on port logistics service during practice process, to find out the shown problems, so as to put forward solutions in their thesis of graduation, it is required to carry out new conceiving and designing for port logistics service process in their solutions, and to put forward strategies and methods for new solutions implementing and operating, then to finish whole process of the applied port logistics management talents training.

\section{POLICY OF THE APPLIED PORT LOGISTICS MANAGEMENT TALENTS TRAINING}

\subsection{Safeguard measures for practical teaching system}

Generally speaking, the place for port logistics practical teaching includes classrooms, laboratories, public professional training centers and outsideschool practical bases, these three kinds of practice place for talents training with different function and effect, to organically combine three kinds of practical place, the student' initiative for studying will be enhanced, which will provide powerful 
support for the implement of CDIO talents training concept.

\subsection{Teaching methodology reform}

During the process of the applied port logistics management talents training, we should carry out teaching methodology reform actively, fully runs through CDIO teaching concept, to arouse students' initiative of study, so as to get good teaching effects on application ability training. During the teaching process that teaching methodology such as Muddy card, self-selected topic, projects study, stimulation and case study can be adopted to arouse students' initiative of study and to play their active role.

\subsection{Evaluation methods reform system}

Use evaluation concept of CDIO, to set up three dimensions evaluation system for applied port logistics management talents training, which is subjects' knowledge: ability of communication and coordination, service (products), process and system construction and operation ability. With this three aspects to evaluate the degree of study goal that students need to achieve. During the process of evaluation the design-implement of port logistics service process should pay attention to, ask students to show their conceiving, designing, implementing and simulating operating port logistics service products, process and ability of system construction, to check the study effect that students acquired from projects experience.

\subsection{Construction of teaching staff}

In the process of the talents training for the applied port logistics management, the requirements for the teachers are who can teach courses that combined with subject knowledge, interpersonal ability and construction ability for products, process and system, which requires the teacher who should have corresponding kinds of ability. With forms of recruiting teachers who have rich practical experience on port logistics management, teachers for theory teaching taking temporary post, further steps for advanced studies and further studies to improve the quality of teaching staff.

\subsection{Construction of teaching material}

The circumstance of working behind the closed doors and pure theory description should be avoided in the process of teaching material construction for port logistics management, the characteristics of port logistics management practice should be combined, to make serial teaching material for port logistics management use not only meet the requirements of the applied port logistics management talents training, also with certain characteristics of practicality and forward-looking.

\section{CONCLUSIONS}

With increasing development of modern port logistics, the demands for the applied port logistics management talents have become more and more pressing. Under the guidance of CDIO concept, to carry out discussion form construction of curriculum system, training for practical ability, teaching methods reform, and adjustment of evaluation methods and other aspects to the specific content of port logistics management talents training, in the hope of applying CDIO talents training concept, to construct more scientific talents training module for the applied port logistics management, to substantially improve the training quality of the applied port logistics management talents, to meet the port logistics development requirements for the applied logistics management talents.

\section{REFERENCES}

[1] Chang-jiang Wang, 2010. Port logistics. Zhejiang University press: 8-10.

[2] Shi-jun Pang, 2008. "Review of Concept of Professional Abilities and Its Relative Problems." Vocational and Technical Education, Vol.28:17-20.

[3] Fan-xing Meng, 2010. "Building Course System of Information Management Based on CDIO." IT Education, No6:98-100.

[4] Pei-hua Gu, Sheng-ping Li, 2009. "Training mode of EIP CDIO innovative engineering talents based on design oriented." China Higher Education, No3:47-49.

[5] Gui-zhi Ding, 2012. "The localization application of 12 CDIO standards: design -- implementation experience." IT Education, No9:96-100. 